\title{
SKRINING DAN IDENTIFIKASI BAKTERI PENDEGRADASI INULIN DARI SUMBER AIR PANAS PADANG BALIMBIANG DI SOLOK
}

\author{
Minda Azhar $^{1,2}$, Sumaryati Syukur ${ }^{3}$, Dessy Natalia ${ }^{4}$, Vovien $^{5}$, Jamsari $^{5}$ \\ ${ }^{1}$ Pascasarjana Universitas Andalas, Program Doktor Ilmu Kimia. Universitas Andalas. \\ Kampus Unand Limau Manis Padang. Indonesia \\ ${ }^{2}$ Laboratorium Biokimia, Fakultas Matematika dan Ilmu Pengetahuan Alam. Universitas \\ Negeri Padang. Jl. Prof. Hamka. Air Tawar Padang. Indonesia. \\ E-mail: minda@fmipa.unp.ac.id \\ ${ }^{3}$ Laboratorium Biokimia, Fakultas Matematika dan Ilmu Pengetahuan Alam. Universitas \\ Andalas Kampus Unand Limau Manis Padang. Indonesia \\ ${ }^{4}$ Kelompok Riset Biokimia, Fakultas Matematika dan Ilmu Pengetahuan Alam, Institut \\ Teknologi Bandung. Jl.Ganesha 10 Bandung.40132. Indonesia. \\ ${ }^{5}$ Laboratorium Bioteknologi. Fakultas Pertanian. Universitas Andalas. Kampus Unand Limau \\ Manis. Padang. Indonesia
}

\begin{abstract}
Thermophilic bacteria and thermotolerant bacteria are potential sources of thermostable of inulin degradating enzyme, an enzyme which converts inulin into fructose and FOS prebiotics. Isolation and identification of $16 \mathrm{~S}$ rDNA gene inulin degradation bacteria from hot springs of Padang Balimbiang in Solok have been undertaken. Screening of inulin degradation bacteria was done using direct and undirect methods on medium with inulin or inulin-RBB as a sole carbon source. One inulin degradation bacteria have been obtained from 21 isolates. The isolate was designated as UBCT-030. The isolate is able to grow at temperature $23{ }^{\circ} \mathrm{C}$ to $60{ }^{\circ} \mathrm{C}$. According to $16 \mathrm{~S}$ rDNA gene analysis, phisiology and morphology bacteria on UBCT-030 isolate was identified as Bacillus subtilis.
\end{abstract}

Keywords: inulinase bacteria, hot springs, Bacillus subtilis, inulin, $16 \mathrm{~S}$ rDNA gene

\section{DAFTAR PUSTAKA}

1. C. F. Phelps, The physical properties of inulin solution, Biochem. J., 95: 41-47, (1965).

2. C. Vielle and G. J. Zeikus, Hyperthermophilic enzymes: sources, uses, and molecular mechanisms for thermostability, Microbiology and Molecular Biology Reviews, American Society Microbiology., 1-43, (2001).

3. J. J. Allais, G. H. Lopez, S. Kammoun, and J. C. Baratti, Isolation and characterization of the thermophilic bacterial strain with inulinase activity, Applied and enviromental microbiology., 53(5): 942945, (1987).
4. A. N. Souza and M. L. L. Martins, Isolation, properties, and kinetics of growth of a thermophilic bacillus, Brazillian Journal of Mirobiology., 32: 271-275, (2001).

5. W. Gao, Y. Bao, Y. Liu, and X. Zhang, Characterization of thermostable endonulinase from a new strain bacillus smithii T7, Appl Biochem Biotechnol., DOI 10.1007/s12010-008-8313-1, (2008).

6. http://www.ncbi.nlm.gov/, 21/02/2012

7. G. R. Castro, M. D. Baigori, and F. Sineriz, a Plate technique for screening of inulin degrading microorganisms, Journal of Microbiological Methods., 22: 51-56, (1995).

8. N. F. Andyani, Produksi sirup fruktosa dari inulin dahlia pinata cav secara hidrolisis asam, Skripsi, Fakultas Teknologi Pangan IPB, Bogor, (2001). 
9. M. Azhar, B. Oktavia, Y. Ma'aruf, Khairani, dan D. Efri, Penentuan kadar rbb pada senyawa inulin-rbb secara HPLC, Jurnal Riset Kimia., 4(2), (2011).

10. K. Tamura, D. Peterson, N. Peterson, G. Stecher, M. Nei, and S. Kumar, MEGA5: Molecular evolutionary genetics analysis using maximum likelihood, evolutionary distance, and maximum parsimony methods, Mol. Biol. Evol., 28(10): 27312739, (2011).

11. http://www.ebi.ac.uk/Tools/msa/clustalw2

12. A. S. S. Ibrahim and A. El-diwany, Isolation and identification of new cellulases producing thermophilic bacteria an egyptian hot spring and some properties of the crude enzyme, Australian Jurnal of Basic and Applied Sciences., 1(4): 473-478, (2007).
13. R. J. Case, Y. Boucher, I. Dahllof, C. Holmstrom, W. F. Doolittle, and S. Kjelleberg, Use 16S rRNA and rpoB genes as molucular markers for microbial ecology studies. Applied and Environmental Microbiology., 73(1): 278-288, (2001).

14. http://www.ncbi.nlm.nih.gov, 09/02/2012

15. A. Pangastuti, Definisi spesies prokaryota berdasarkan urutan basa gen penyandi $16 \mathrm{~s}$ rrna dan gen penyandi protein, Biodiversitas., 7(3): 292-296, (2006).

16. J. G. Holt, N. R. Krieg, P. H. A. Sneath, J. T. Staley, and S. T. William, Bergey' manual of determinative bacteriology, edisi 9, The William \& wilkins Co.Inc, 1994. 